\title{
Population structure of Callichirus major (Say 1818) (Crustacea: Callianassidae) and conservation considerations at Southeast coast of São Paulo, Brazil
}

\author{
FERNANDA A. MOSCHETTO, LUIS FELIPE A. DUARTE \& ROBERTO P. BORGES
}

\begin{abstract}
Globally, there is limited knowledge about management and conservation of Callianassidae family. Their catches seem to be recently increasing in several parts of the world and evidences raise concern on the need of specialized literature focused on populations monitoring. At Southeast of Brazil, the species Callichirus major (Say 1818), known as the ghost shrimp, is frequently captured for use as bait in sport fishing and, according to previous studies, the overexploitation could threaten the population. The aim of this study was evaluated over a year this harmful human pressure on the species C. major in two beaches contiguous but susceptible to different anthropogenic impacts due to the existence of legislation on one beach that prohibits the capture of this crustacean. The population of C. major presented where the prohibition regulation does not exist a density almost three times lower when compared to the beach that prohibits the capture, with individuals with smaller carapace oval area and a shorter reproductive period. This paper alert to some evidence of $C$. major structure population disturbance resulting from its exploitation at Southeast of Brazil. Recommendations were also addressed to conservation management considering the species' ecological importance.
\end{abstract}

Key words: Callianassidae, ghost shrimp, conservation, overexploitation, sandy beaches, crustacean.

\section{INTRODUCTION}

The burrowing crustaceans of the species Callichirus major (Say 1818) (Crustacea: Axiidea) belongs to the family Callianassidae (Dana 1852) which are known as ghost shrimps, occurring in galleries excavated in the sediment of the intertidal region of sandy beaches. Its presence is detected on the surface of the sand through characteristic holes of $5 \mathrm{~mm}$ in diameter with surrounded by fecal pellets (Weimer \& Hoyt 1964, Frankenberg et al. 1967, Rodrigues \& Shimizu 1997, Botter-Carvalho et al. 2007, AlvesJúnior et al. 2014a, 2018). It is distributed from North Carolina in the United States to the state of Santa Catarina in Brazil (Rodrigues 1983, Coelho \& Ramos-Porto 1986, Manning \& Felder 1986, Melo 1999, Dworschak 2000).

This crustacean has great ecological importance because it favors the establishment of other species in its galleries, such as bivalves, polychaetes and other crustaceans (Rodrigues \& Shimizu 1997, Berkenbusch et al. 2000, Souza \& Borzone 2003, Peiró \& Mantellato 2011, 2016). It also performs bioturbation, revolving the sediment and increasing the cycling of organic matter and nutrients in its zones of occupation (Webb \& Eyre 2004, Abrunhosa et al. 2008). 
However, C. major individuals are frequently captured for use as bait in sport fishing along the Brazilian coast (Souza \& Borzone 2003, Botter-Carvalho et al. 2007) and this excessive activity has been resulting in a decline in the species' population (Botter-Carvalho et al. 2007, Peiró \& Mantelatto 2016) and even causing overexploitation (Souza \& Borzone 2003, Rodrigues \& Shimizu 1997). Apart from overfishing, it is also recognized that others possible factors could affect its densities, such as sediment size (Borzone \& Souza 1996, Dumbald et al. 1996, Strasser \& Felder 1999, Dworschak 2000, Botter-Carvalho et al. 2002), individual body size (Botter-Carvalho et al. 2007, Alves-Júnior et al. 2014b, 2018) and food availability (Suchanek \& Colin 1986, Rodrigues and Shimizu 1997).

The simple observation of the intensification of capturing of the species led to the creation of law 850 in 1992, prohibiting the exploitation of these animals throughout the municipality of Santos, state of São Paulo, southeast of Brazil, even collection for scientific purposes. Notably, this law was created using no scientific support, such as the description of density and population structure of the species. However, seventeen years later, Pedrucci and Borges (2009) found higher densities of the species at the José Menino Beach (where the catching of $C$. major is prohibited) than at the Itarare Beach, located in São Vicente (where the catching of $C$. major is not prohibited), bordering the Santos city. This would be the first evidence showing the effectiveness of the law. Other studies have also shown that beaches free from anthropogenic influence have demonstrated higher density of callianassids species (Wynberg \& Branch 1997, Contessa \& Bird 2004, Hernaéz \& Wehrtmann 2007). Based on these statements, it is believed that the prohibition of the capture of $C$. major in one of the beaches may contribute to the conservation of the species as confirmed by these authors. Even though the capture of the species may occurs illegally in Santos, the exploitation is unquestionably less intense due to effective monitoring by cameras (24 hours per day) and municipal guards. In addition, the population structure of $C$. major in the beach where there is no specific legislation, as the Itarare Beach, may be subject to changes because of excessive catch observed in this area.

Based on that, the aim of this study was analyzing the influence (even as first evidence) of exploitation of C. major in terms of their densities at Itararé and José Menino, two contiguous beaches but susceptible to different anthropogenic impacts due to local specific legislation. In addition, at the the Itararé Beach (where capture is not prohibited), a secondary objective was to describe the biological aspects of the species particularly based on sex ratio, population structure in terms of length and gender and reproductive periods, in order to compare them with other studies and identify possible changes in the population, due to the intense exploitation of these animals at the Itararé Beach.

\section{MATERIALS AND METHODS}

\section{Study area}

Itararé Beach in São Vicente (361803.06 m E and 7348449.56 m S, UTM, Datum WGS 84), where there is no specific legislation prohibiting the capture of C. major, and José Menino Beach in Santos (362859.12 m E and $7348518.91 \mathrm{~m} \mathrm{~S}$, UTM, Datum WGS 84), where law 850/1992 prohibits the capture of the species, are located in Santos Bay, state of São Paulo, southeastern Brazil (Figure 1). The beaches present a dissipative morphodynamic state and they are very environmentally similar to each other, with homogeneous profiles composed of fine to 


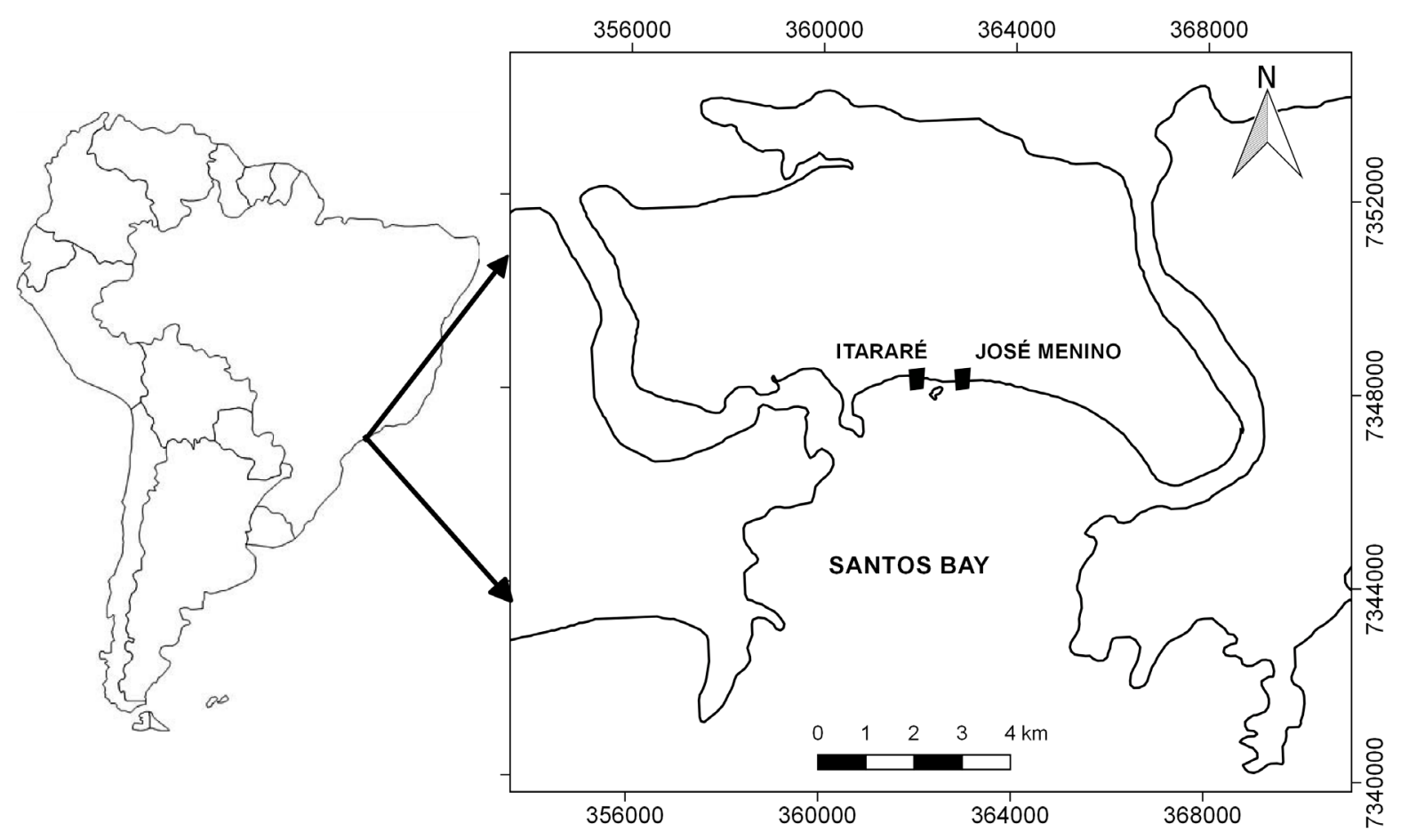

Figure 1. Location of the study beaches in Santos Bay, state of São Paulo, Brazil Google Earth (2018). UTM, Datum WGS 84.

very fine sands (Farinaccio et al. 2009). Both are very urbanized, however, only Santos beaches counted with intensive monitoring in order to enforce the law regarding the capture of $C$. major.

\section{C. major: assessment of density and population structure}

The estimation of species density was based on the method used by Souza \& Borzone (2003) and Botter-Carvalho et al. (2002). Four transects were arranged randomly in the intertidal region on the both beaches, perpendicular to the water line, and each transect was composed of contiguous sample units of $1 \mathrm{~m}^{2}$. The densities were calculated monthly from September 2013 to September 2014 during low tide periods based on the number of burrow holes in each sample unit. As corroborated by Rodrigues
(1983), each burrow hole was considered one unique individual, except in reproductive period. In addition, it is important to mention that only this species of callianassids occurs on beach tidal region (band analyzed in this study) (Rodrigues 1983). For statistical data treatment, the densities per $\mathrm{m}^{2}$ obtained in an each transect were compared between beaches and between months using the non-parametric Kruskal-Wallis test (Zar 1999).

The population structure was evaluated only at the Itararé Beach from October 2013 to September 2014. The sampling occurred monthly in each four transects in burrows located right on the boundary of the water line, due to the greater probability of sampling of the species in this section as described by Souza et al. (1998). A single researcher performed all the samplings 
collection using a suction pump, with a sampling effort of 30 minutes in each transect.

Specimens captured monthly were placed in containers containing alcohol (70\%) and transported to the laboratory, where they were brushed to remove sand and measured with 0.05-mm precision calipers (carapace oval area length). According to Rodrigues \& Shimizu (1997), the oval area corresponds to an isometric structure to the total length of the animal's body.

The sex was also determined by inspection of the first pair of pleopods and sexual dimorphism of the chelipeds (Botter-Carvalho et al. 2007), and the sex ratio was analyzed by the Chi-Square test (Zar 1999). The reproductive period was determined through the months of occurrence of ovigerous females in the population, as proposed by Butler et al. (2009).

\section{Environmental characteristics of the beaches: organic matter and granulometry}

In order to assure that some possible differences of densities in the two beaches were accounted for, the two main natural causes that determine the population size were investigated: organic matter and grain size (Borzone \& Souza 1996, Rodrigues \& Shimizu 1997, Dworschak 2000, Botter-Carvalho et al. 2007). Analysis of the organic matter present in the intertidal zone was performed monthly by burning the dry sediment at $550{ }^{\circ} \mathrm{C}$ for two hours and the organic content calculated as the difference between the initial and final weights divided by the initial sample weight times 100\% (Suguio 1973). The mean grain size of the sediments present in the intertidal zone was determined also monthly using the method proposed by Folk \& Ward (1957) which still used in other studies (Botter-Carvalho et al. 2002, Souza \& Borzone 2003).

These results of the environmental characteristics were correlated with the densities of C. major through the Spearman correlation coefficient. Posteriorly, the similarity between the beaches based on their environmental aspects was analyzed using the Kruskal-Wallis test.

\section{RESULTS}

\section{Density Analysis}

The density of C. major ranged from 0 to 18 ind. $\mathrm{m}^{2}$ at the Itarare Beach (mean density of 1.33 ind. $\mathrm{m}^{2}$ to 4.50 ind. $\mathrm{m}^{2}$ ) and from 0 to 20 ind. $\mathrm{m}^{2}$ at the José Menino Beach (mean density from 5.07 ind. $m^{2}$ to 8.47 ind. $\mathrm{m}^{2}$ ) (Figure 2).

José Menino Beach presented significantly higher densities than those observed in Itararé Beach in all months studied $(p<0.0001)$. There was also a significant difference of density between months in both beaches $(p<0.0001)$, evidencing a population variation in the temporal distribution of the species. However, there were no peaks of densities indicating a defined seasonal period for the abundance of the species in both beaches.

The sediments of the intertidal regions were composed of fine to very fine sand (average diameter of 0.11 to $0.25 \mathrm{~mm}$ ) and presented varying concentrations of organic matter ( 0.30 to $4.27 \%$ of the dry weight of the samples).

The beaches are similar as regards their mean grain size $(p=0.246)$ and the organic content ( $p=0.375)$. However, these environmental factors did not correlate with the densities in the studied beaches $(r<0.04, p<0.05)$.

A total of 382 individuals of C. major (156 males and 226 females) were collected in the Itarare Beach, with predominance of females (1:1.44, $\left.X^{2}=12.82, p=0.0005\right)$.

The length of the oval area ranged from 2.63 $\mathrm{mm}$ (smaller male collected in October 2013) to $11.88 \mathrm{~mm}$ (largest male collected in July 2014), with males and females presenting a modal length in the class of 8-9 $\mathrm{mm}$. 
The ovigerous females were recorded in the Itararé Beach from December 2013 to March 2014 (7.07\% of the total females sampled) and their relative record monthly were $15.38 \%$ in December, 27.27\% in January, 36.84\% in February and 5.55\% in March. These individuals presented an oval length ranging from $8.09 \mathrm{~mm}$ (December 2013) to $10.88 \mathrm{~mm}$ (March 2014) (mean of $9.19 \pm 0.73$ ). Table I shows the monthly means obtained for this structure, incluing the number of males, females and ovigerous females sampled during the study months.
Considering all of the individuals sampled, significant differences in the oval length were found among the months ( $p<0.0001)$, suggesting oscillations in the body sizes throughout the study.

\section{DISCUSSION}

The densities of individuals of C. major at José Menino were higher than those recorded at Itararé and superior than the results obtained at José Menino by Rodrigues (1983) (1.5 to 7.9 ind.

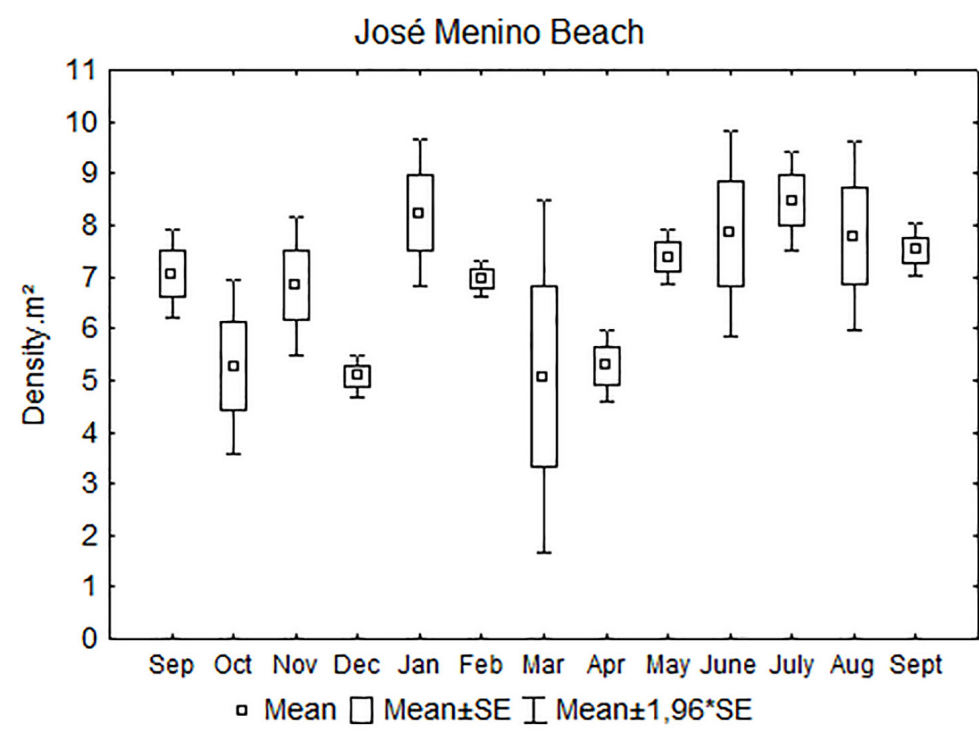

Figure 2. Densities of $C$. major at José Menino and Itararé monthly from September 2013 to September 2014.

Itararé Beach

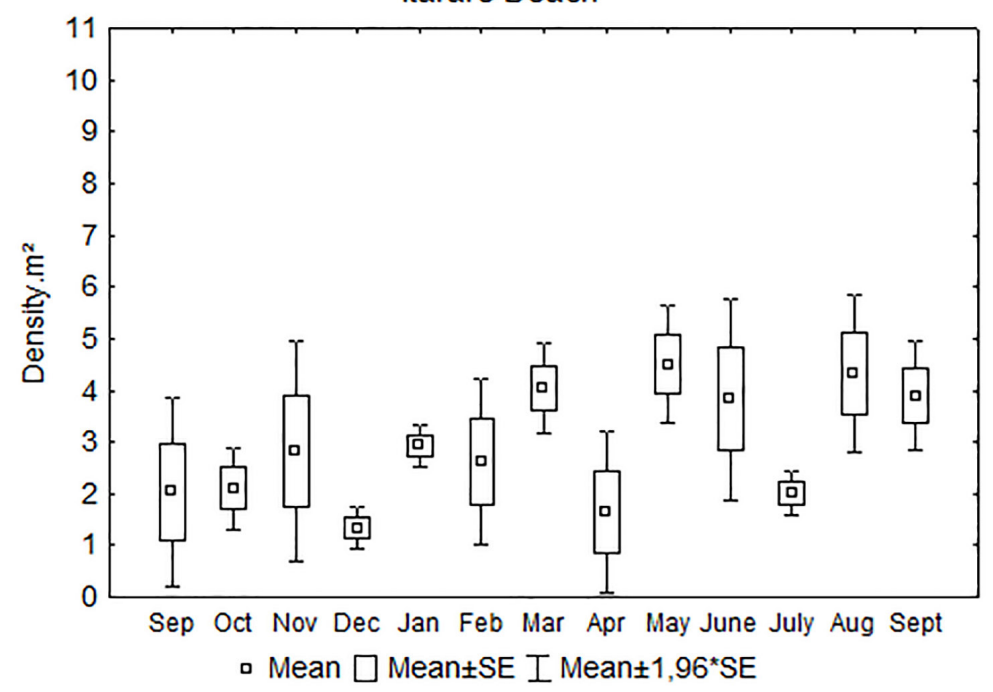


Table I. Monthly mean oval lengths $(\mathrm{mm})$ of $C$. major specimens sampled at the Itararé Beach, São Vicente, state of São Paulo.

\begin{tabular}{|c|c|c|c|c|c|c|c|c|c|c|}
\hline \multirow{2}{*}{\multicolumn{2}{|c|}{ Study months }} & \multirow{3}{*}{$\begin{array}{l}\mathbf{N} \\
12\end{array}$} & \multicolumn{2}{|l|}{ Males } & \multirow{3}{*}{$\begin{array}{l}\mathbf{N} \\
27\end{array}$} & \multicolumn{2}{|c|}{ Females } & \multicolumn{3}{|c|}{ Ovigerous } \\
\hline & & & \multirow{2}{*}{$\begin{array}{c}\text { Mean length } \\
5.72\end{array}$} & \multirow{2}{*}{$\begin{array}{l}\text { Sd } \\
1.26\end{array}$} & & \multirow{2}{*}{$\begin{array}{c}\text { Mean length } \\
7.22 \\
\end{array}$} & \multirow{2}{*}{$\begin{array}{l}\text { Sd } \\
0.91\end{array}$} & \multirow{2}{*}{$\begin{array}{l}\mathbf{N} \\
-\end{array}$} & \multirow{2}{*}{$\begin{array}{c}\text { Mean length } \\
-\end{array}$} & \multirow{2}{*}{$\begin{array}{c}\text { Sd } \\
-\end{array}$} \\
\hline & October & & & & & & & & & \\
\hline$\check{n}^{2}$ & November & 10 & 7.34 & 0.64 & 28 & 7.51 & 0.97 & - & - & - \\
\hline & December & 21 & 8.30 & 0.95 & 13 & 8.60 & 0.57 & 2 & 8.45 & 0.36 \\
\hline \multirow{9}{*}{$\stackrel{\nu}{\dot{\nu}}$} & January & 14 & 8.29 & 1,15 & 22 & 8.93 & 0.72 & 6 & 9.01 & 0.50 \\
\hline & February & 15 & 9.18 & 1.12 & 19 & 9.10 & 1.04 & 7 & 9.32 & 0,54 \\
\hline & March & 10 & 8.52 & 1.30 & 18 & 8.87 & 1.17 & 1 & - & - \\
\hline & April & 7 & 9.10 & 0.92 & 11 & 6.96 & 1.61 & - & - & - \\
\hline & May & 7 & 8.34 & 1.87 & 20 & 7.37 & 1.56 & - & - & - \\
\hline & June & 8 & 8.52 & 1.56 & 9 & 8.15 & 1.74 & - & - & - \\
\hline & July & 14 & 8.06 & 1.48 & 14 & 8.51 & 1.05 & - & - & - \\
\hline & August & 25 & 7.34 & 1.09 & 23 & 8.51 & 1.30 & - & - & - \\
\hline & September & 13 & 7.95 & 0.89 & 22 & 8.19 & 1.45 & - & - & - \\
\hline
\end{tabular}

$\mathrm{m}^{2}$ ) and by Rodrigues \& Shimizu (1990) (1.5 to 7.9 ind. $m^{2}$ ). Pedrucci \& Borges (2009) found higher values than those obtained in this study for $C$. major at José Menino (mean density of 14.39 ind. $\mathrm{m}^{2}$ ) and lower density (2.23 ind. $\left.\mathrm{m}^{2}\right)$ at Itararé.

The increase in the number of individuals of C. major at José Menino over the years is possibly associated with the protective law. In the present study, the density was almost three times higher than that observed at the Itararé beach. Hypothetically, this population difference could be the consequence of the creation of the municipal law 850/1992. It is believed that even if the capture of C. major may occurs illegally at José Menino, the municipal law implies in lowest intensity of this activity.

Table II shows that the densities of the species of callianassids are variable in several localities, even in sandy beaches with morphodynamics characteristics similar to beaches evaluated in this study. Most of the authors reported the occurrence of capture activity of the callianassids in these localities, except by Felder and Griffs (1994).
Other factors (abiotic and biotic) could be determining the size of the local populations, while the differences found to the beaches studied could be an effect from the exploitation prohibition, since they are connected geographically.

No defined seasonal periods were identified for the densities in the both beaches, different from the study developed by Souza et al. (1998) and Souza \& Borzone (2003), who found the highest densities of the species in the summer (rainy season) in the southern region of the country. Botter-Carvalho et al. (2002) reported a decline in C. major densities from the month of April (beginning of rainy season) in a beach at the northeast of Brazil. Perhaps the temperature is more deterministic in influencing the density of the species than the rains.

It is important to mention the impossibility of the occurrence of more than one animal per gallery for the C. major according to Rodrigues (1983). The occasional meeting between C. major individuals in the galleries leads immediately to competition and reproduction (Rodrigues \& 
Table II. Densities of callianassids in various localities along the American Coast (Atlantic and Pacific Ocean).

\begin{tabular}{|c|c|c|c|}
\hline Species & Locality & Density (ind.m²) & References \\
\hline $\begin{array}{l}\text { Callichirus islagrande } \\
\quad \text { (Schmitt ,1935) }\end{array}$ & Louisiana, EUA & mean of 150 & Felder \& Griffs (1994) \\
\hline $\begin{array}{c}\text { Lepidophthalmus } \\
\text { louisianensis (Felder and } \\
\text { Rodrigues, 1993) }\end{array}$ & Mississipi, EUA & mean of 400 & Felder \& Griffs (1994) \\
\hline $\begin{array}{l}\text { Callichirus seilacheri (Bott, } \\
\text { 1955) }\end{array}$ & Las Machas Beach, Chile & 1.4 to 20.2 & $\begin{array}{l}\text { Hernaéz \& Wehrtmann } \\
\text { (2007) }\end{array}$ \\
\hline Callichirus major & Coast of Paraná, south coast of Brazil & 0.12 to 11.42 & Borzone \& Souza (1996) \\
\hline Callichirus major & $\begin{array}{c}\text { Atami Beach, Paraná, south coast of } \\
\text { Brazil }\end{array}$ & mean of 10.1 & Souza et al. (1998) \\
\hline Callichirus major & $\begin{array}{c}\text { Leste Beach, Paraná, south coast of } \\
\text { Brazil }\end{array}$ & 8.5 to 9.3 & Souza \& Borzone (2003) \\
\hline Callichirus major & $\begin{array}{l}\text { Piedade Beach, Pernambuco, } \\
\text { northeast coast of of Brazil }\end{array}$ & mean of 6.07 & $\begin{array}{l}\text { Botter-Carvalho et al. } \\
\qquad(2002)\end{array}$ \\
\hline Callichirus major & $\begin{array}{l}\text { Itararé Beach, Southeast coast of São } \\
\text { Paulo, Brazil }\end{array}$ & mean of 2.63 & Present study \\
\hline Callichirus major & $\begin{array}{c}\text { José Menino Beach, Southeast coast } \\
\text { of São Paulo, Brazil }\end{array}$ & mean of 6.41 & Present study \\
\hline
\end{tabular}

Shimizu 1997), a behavior attributed by Felder \& Lovett (1989) to territorial defense or mating. The densities of the Sergio mirim (Rodrigues 1971) was not considered too, since their occurrence and distribution in deeper areas (Rodrigues 1983), a fact that attributed greater accuracy to the density of $\mathrm{C}$. major estimated.

Although previous studies indicate that sediments composed of fine to very fine sand support the occurrence of high densities of C. major (Borzone \& Souza 1996, Rodrigues \& Shimizu 1997, Dworschack 2000, Souza \& Borzone 2003, Botter-Carvalho et al. 2007), the results recorded in both beaches did not indicate the influence of this factor. Pinheiro et al. (2011) analyzed the density of C. major at the beaches in Santos close and distant from the drainage channels (constructed mainly to drain rainwater from the urban region), but these authors recorded a higher density of $C$. major associated with this human intervention as a consequence of higher organic material local content. However, the content of organic matter in this study was not correlated with the densities.

The higher density of C. major at the José Menino Beach when compared to the density at the Itararé Beach, similar as observed by Pedrucci \& Borges (2009), could be a consequence of the lower capture effort by fishermen over time in the area due to law 850/1992, which prohibits the catching of this crustacean, considering that the beaches are similar in environmental aspects (organic content and sediment size), connected geographically, and that these facts did not influence the densities obtained.

The capture of individuals can cause fluctuations in the density and temporal distribution of the species. Overexploitation does not require the removal of large quantities of specimens from the beaches due to distinct biological potential that species have for their repopulating that also depend of environmental quality. 
Table III. Reproductive periods of $C$. major and other callianassids in different localities.

\begin{tabular}{|c|c|c|c|}
\hline Species & Locality & Reproductive period & References \\
\hline $\begin{array}{l}\text { Sergio mirim (Rodrigues, } \\
\text { 1971) }\end{array}$ & $\begin{array}{l}\text { Cassino Beach, Rio } \\
\text { Grande do Sul, south } \\
\text { coast of Brazil }\end{array}$ & September-January & Pezzuto (1998) \\
\hline $\begin{array}{l}\text { Callichirus seilacheri } \\
\text { (Bott ,1955) }\end{array}$ & Las Machas Beach, Chile & March-September & $\begin{array}{l}\text { Hernaéz and Wehrtmann } \\
(2007)\end{array}$ \\
\hline Callichirus major (Say, 1818) & $\begin{array}{l}\text { Atami Beach, Paraná, } \\
\text { south coast of Brazil }\end{array}$ & November-January & Souza et al. (1998) \\
\hline Callichirus major (Say, 1818) & $\begin{array}{l}\text { Piedade Beach, } \\
\text { northeast coast of Brazil }\end{array}$ & December - May & $\begin{array}{l}\text { Botter-Carvalho et al. } \\
\text { (2007) }\end{array}$ \\
\hline $\begin{array}{c}\text { Trypaea australiensis (Dana, } \\
\text { 1852) }\end{array}$ & $\begin{array}{c}\text { Western Port, Victoria, } \\
\text { Australia }\end{array}$ & September - December & Butler et al. (2009) \\
\hline $\begin{array}{c}\text { Biffarius arenosus (Poor, } \\
\text { 1975) }\end{array}$ & $\begin{array}{c}\text { Western Port, Victoria, } \\
\text { Australia }\end{array}$ & September - February & Butler et al. (2009) \\
\hline Callichirus major (Say, 1818) & $\begin{array}{l}\text { Itararé Beach, Southeast } \\
\text { coast of São Paulo, Brazil }\end{array}$ & December - March & Present study \\
\hline
\end{tabular}

Some vulnerable species can present significant declines in population even with relatively minimal fishing effort levels (Tamaki \& Ingole 1993, Kura et al. 2004, Duarte et al. 2010, 2014, FAO 2018). Wynberg and Branch (1997) confirmed through experiments that the catching of the callianassid Callianassa kraussi (Stebbing 1990) in South Africa from the use of suction pumps caused a decline in the population density of this species, as well as a destruction of its galleries. In Australia, a study by Contessa and Bird (2004) also showed the capture of the callianassid Trypaea australiensis (Dana 1952) using a suction pump caused a reduction in the densities due to changes in sediment properties, such as porosity and oxidation, creating conditions unfavorable for the occupation of the species. Hernaéz and Wehrtmann (2007) affirmed that the catching of Callichirus seilacheri (Bott 1955) for use as bait in fishing can affect density considerably over time.

As regards the population structure, females predominated in the sampled population, consistent with other studies (Rodrigues et al.
1994, Rodrigues \& Shimizu 1997, Souza et al. 1998, Botter-Carvalho et al. 2007). This proportion can be explained because most of the male callianassids construct deeper galleries, making them harder to capture with a suction pump (Rodrigues \& Shimizu 1997).

As for the months of occurrence of ovigerous females, the reproductive period was seasonal (December to March), diverging from the results of Rodrigues (1983) and Rodrigues et al. (1986), who obtained ovigerous females over the course of one year at José Menino, and Peiró et al. (2014), who collected ovigerous females over one year at the northern coast of the state of São Paulo. Different reproductive periods reported for $C$. major and other callianassids can be seen on Table III.

Proportionally, low numbers of ovigerous females were sampled at Itararé in comparison to the studies carried out at José Menino by Rodrigues et al. (1994) (41.3\%) and Rodrigues \& Shimizu (1997) (45\%), by Peiró et al. (2014) at the northern coast of the state of São Paulo (41\%), and by Botter-Carvalho et al. (2007) (21.40\%) at the northeast of Brazil. Botter-Carvalho et al. 
(2007) stated that ovigerous females tend to move to the top of the galleries in order to expose their eggs to ventilation and can therefore be captured more easily. However, contrary to this statement, Peiró et al. (2014) mentioned that ovigerous females tend to inhabit the bottom of the galleries, making the capture of these individuals difficult with the suction pump. According to Hernáez et al. (2008), the males of C. major fertilize low numbers of females during mating events, resulting in low ovigerous abundance. There is still the possibility of the capture of individuals of larger body sizes for use as bait, and this would include the removal of adult or ovigerous females from the populations (McPhee \& Skilleter 2002).

The size of ovigerous females recorded (8.09-10.88 mm) was lower than those observed in other studies (11.91-16.2 $\mathrm{mm}$ by Sendim et al. 2007 and 10.3-15 mm by Peiró et al. 2014). Similar smaller sizes those obtained in the present study were found by Souza et al. (1998) (minimum of 8.5 ) and Botter-Carvalho et al. (2007) (7.2-12.6 mm) precisely in beaches where an overexploitation of the population was documented. According to Sparre \& Venema (1998) and Kura et al. (2004) a population could reproduce earlier under fishing pressure.

In terms of body sizes of the all individuals, the mode of the oval length registered at Itarare for both sexes $(8.08 \pm 1.41 \mathrm{~mm})$ was inferior to results obtained at José Menino by Rodrigues et al. (1994) (12 $\mathrm{mm}$ for this structure in both sexes). The results are also lower than those found by Rodrigues \& Shimizu (1997) at the same beach, where the authors related the displacement of the mode to the lower classes (from 15 to $12 \mathrm{~mm}$ ) and associated this fact with the increase in the number of juveniles, as a result from overexploitation of $C$. major. In the present study was observed for all months a mean of oval length smaller than $9 \mathrm{~mm}$, which refute the supposed high frequency of juveniles and could be related to the recruitment period of the species.

In addition, a temporal body size decrease is usually an indicator for identifying overexploited populations (Sparre \& Venema 1998, Kura et al. 2004).

The body oscillations evidenced throughout this study differentiate from the data obtained by Rodrigues et al. (1986), who found no variation over time in the oval length at José Menino and affirmed that the growth of the individuals was slow. Thus, the importance of a new sampling of C. major individuals at José Menino is evident in order to evaluate their population structure and update information about the population structure and reproductive biology. At the northeastern region of Brazil, Botter-Carvalho et al. (2007) detected significant variations over the months in the oval length of $C$. major, linking this event to the excessive capturing of the animals.

Similar to what was observed by Rodrigues and Shimizu (1997), the population structure of C. major may have been affected by excessive species capture in this study region. Furthermore, the capture method may also alter the density and the population structure of the species, as reported in other studies developed with calianassids (Wynberg \& Branch 1994).

Even with the existence of law 850/1992 in Santos, there are no current conservation proposals for the species in Brazil, and as such, the establishment of periods closed to capture or a limit on the number of individuals captured may be necessary (Peiró \& Mantelatto 2016).

The information provided in this study is relevant to understand the current population in order to address strategies about the exploitation management. It will serve to present a general view of the sustainability of the capture of this crustacean as bait to fish at the southern São Paulo State. These findings 
represent a necessary first step toward the maintenance of healthy and sustainable stocks of C. major and other callianassids.

\section{CONCLUSIONS}

Considering that the beaches are contiguous, have similar morphodynamics characteristics and the mean grain size and the organic content present in the sand did not influence the results, it can be assumed that the exploitation (Itararé) and non-exploitation (José Menino) of the $C$. major is leading the significant differences of the densities between the beaches.

In the samesense, the presence of individuals with smaller body sizes in Itarare beach when compared with other studies and a shorter reproductive period, can also inferred that the capture of $C$. major is causing changes in their population structure. Decreasing specimens mean size observed in this paper may result from the fishing mortality, meaning that the individuals of the population cannot reach their maximum body size, and thus, possibly affects negatively the reproductive success and density afterward. Given the ecological importance of C. major, the data presented suggests that the adoption of conservation management, such as the prohibition or control of the collect of specimens by specific law at the Itararé beach, should be necessary.

Other studies about calianassids should be intensified, especially in urban beaches where the population of this group is susceptible to capture for use in fishing activities.

\section{Acknowledgments}

The authors acknowledge the Coordenação de Aperfeiçoamento de Pessoal de Nivel Superior (CAPES) for the scholarship that supported this work. Also, the author Luis Felipe de Almeida Duarte would like to thank the Fundação de Amparo à Pesquisa do Estado de São
Paulo (FAPESP) for awarding financial of his Post Doctoral Scholarship (Cases: \# 2014/13448-2 and \# 2016/05414-6).

\section{REFERENCES}

ABRUNHOSA FA, ARRUDA DC B, DARLAN JB, SMITH JB \& PALMEIRA CAM. 2008. The importance of feeding in the larval development of the ghost shrimp Callichirus major (Decapoda: Callianassidae). An Acad Bras Cienc 80: 445-453.

ALVES-JÚNIOR FA, ARAÚJO MSLC \& COELHO PA. $2014 a$. Population biology of Callichirus major (Say, 1818) (Crustacea: Callianassidae) at Piedade Beach, Brazil. RGCI 14(1): 109-118.

ALVES-JÚNIOR FA, ARAÚJO MSLC \& FEITOSA FAN. 2014 b. Crescimento alométrico de Callichirus major (Say, 1818) (Crustacea: Callianassidae) em uma praia arenosa do Nordeste Brasileiro. Trop Oceanogr 42: 13-21.

ALVES-JÚNIOR FA, SANTANA JL, FIGUEIREDO AMF \& ARAÚJO MSLC. 2018. Population and reproductive biology of Callichirus major (Say, 1818) (Decapoda: Axiidae: Callianassidae) in an urban beach, Northeastern Brazil. PANAMJAS 13(2): 166-178.

BERKENBUSCH K, ROWDEN AA \& PROBERT PK. 2000. Temporal and spatial variation in macrofauna community composition imposed by ghost shrimp Callianassa filholi bioturbation. Mar Ecol Prog Ser 192: 249-257.

BORZONE CA \& SOUZA JRB. 1996. A extração de corrupto Callichirus major (Decapoda: Callianassidae) para uso como iscas em praias do litoral do Paraná: características da pesca. Nerítica 10: 69-79.

BOTTER-CARVALHO ML, SANTOS, PJP \& CARVALHO PVVC. 2007. Population dynamics of Callichirus major (Say, 1818) (Crustacea, Thalassinidea) on a beach in northeastern Brazil. Estuar Coast Shelf Sci 71: 508-516.

BOTTER-CARVALHO ML, SANTOS PJP \& CARVALHO PVVC. 2002. Spatial distribution of Callichirus major (Say, 1818) (Decapoda, Callianassidae) on a sandy beach, Piedade, Pernambuco, Brazil. Nauplius 10(2): 97-109.

BUTLER SN, REID M \& BIRD FL. 2009. Population biology of the ghost shrimps, Trypaea australiensis and Biffarius arenosus (Decapoda: Thalassinidea), in Western Port. Victoria Mem Mus Vic 66: 43-59.

COELHO PA \& RAMOS-PORTO M. 1986. Sinopse dos Crustáceos Decápodos Brasileiros (Famílias Dorippidae e Leucosiidae). Caderno Ômega da Universidade Federal Rural de Pernambuco, Série Ciências Aquáticas 2: 67-77. 
CONTESSA L \& BIRD FL. 2004. The impact of bait-pumping on populations of the ghost shrimp Trypaea australiensis Dana (Decapoda: Callianasidae) and the sediment environment. J Exp Mar Biol Ecol 304: 75-97.

DUARTE LFA, DURAN RS, MENDONÇA JT \& PINHEIRO MAA. 2014. The fishery for the 'uçá'-crab Ucides cordatus (Linnaeus, 1763) in a mangrove area in Cananéia, State of São Paulo, Brazil. I. Fishery performance, exploitation patterns and factors affecting the catches. Braz J Oceanogr 62(3): 187-199.

DUARTE LFA, SEVERINO-RODRIGUES E \& GASALLA MA. 2010. Slipper lobster (Crustacea, Decapoda, Scyllaridae) fisheries off the southeastern coast of Brazil: I. Exploitation patterns between 23000' and 2965'S. Fish Res 102(1): 141-151.

DUMBAULD BR, ARMSTRONG DA \& FELDMAN KL. 1996. Lifehistory characteristics of two sympatric thalassinideans shrimps, Neotrypacea californiensis e Upogebia pugettensis, with implications for oyster culture. J Crust Biol 16: 689-708.

DWORSCHAK PC. 2000. Global diversity in the Thalassinidea (Decapoda). The J Crustac Biol 20: 238-245.

FARINACCIO A, CAZZOLI Y GOYA S \& TESSLER MG. 2009. Variações da linha de costa nas baías de Santos e São Vicente. QEG 01(01): 42-48.

FAO. 2018. Organização das Nações Unidas para a Agricultura e Alimentação. Pesca e Aquicultura. Disponível em: http://www.fao.org. (last access: July 2018).

FELDER DL \& GRIFFS RB. 1994. Dominant infaunal communities at risk in shoreline habitats: burrowing Thalassinid Crustacea. OCS Study, MMS 94 - 0007, U.S. Department of the Interior, Minerals Management Service, Gulf of Mexico OCS Regional Office, New Orleans, $87 \mathrm{p}$.

FELDER DL \& LOVETT D. 1989. Relative growth and sexual maturation in the Estuarine ghost shrimp Callianassa louisianensis (Schimitt, 1935). J Crustac Biol 9(4): 540-553.

FRANKENBERG D, COLES SL \& JOHANNES RE. 1967. The potential trophic significance of Callianassa major fecal pellets. L \& 0 12(1): 113-120.

FOLK RL \& WARD WC. 1957. Brazos River bar, a study in the significance of grain size parameters. J Sed Petrol 27 (1): 2-26.

GOOGLE EARTH. 2018. http://earth.google.com/. Last access: October 2018.
HAMMER O, HARPER DAT \& RYAN PD. 2001. PAST: Paleontological statistics software package for education and data analysis. Palaeontologia Electronica 4 (1): 9pp. http://palaeo-electronica.org/2001_1/past/issue1_01. htm. (last access: June 2018).

HERNÁEZ P, PALMA S \& WEHRTMANN IS. 2008. Egg production of the burrowing shrimp Callichirus seilacheri (Bott 1955) (Decapoda, Callianassidae) in northen Chile. Helgol Mar Res 62: 351-356.

HERNÁEZ P \& WEHRTMANN IS. 2007. Population biology of the burrowing shrimp Callichirus seilacheri (Decapoda: Calianassidae) in northen Chile. Rev Biol Trop 55: 141-152.

KURA Y, REVENGA C, HOSHINO E \& MOCK G. 2004. Why care about fish? In: Kura Y, Revenga C, Hoshino E \& Mock G (Eds), Fishing for Answers, Making Sense of Global Fish Crisis. WRI, Washington, DC, 152 p.

MANNING RB \& FELDER DL. 1986. The status of the callianassid genus Callichirus Stimpson, 1866 (Crustacea: Decapoda: Thalassinidea). Proc Biol Soc Wash 99: 437-443.

MCPHEE DP \& SKILLETER GA. 2002. Harvesting of intertidal animals for bait for use in a recreational fi shing competition. Proc R Soc Queensl 110: 93-101.

MELO GAS. 1999. Manual de identificação dos Crustacea Decapoda do litoral brasileiro: Anomura, Thalassinidea, Palinuridea, Astacidea. Editora Plêiade/FAPESP, São Paulo.

PEDRUCCI ACC \& BORGES RP. 2009. Determinação de densidade populacional de Callichirus major na Praia de José Menino - Santos e Itararé - São Vicente. Rev Ceciliana 1(2): 121-125.

PEIRÓ DF \& MANTELATTO FL. 2011. Population dynamics of the pea crab Austinixa aidae (Brachyura, Pinnotheridae): a symbiotic of the ghost shrimp Callichirus major (Thalassinidea, Callianassidae) from the southwestern Atlantic. Iheringia, Sér Zoo 101: 5-14.

PEIRÓ DF \& MANTELATTO FL. 2016. Avaliação do calianassídeo Callichirus major (Say, 1818) sensu lato. In Livro Vermelho dos Crustáceos do Brasil: Avaliação 2010-2014, Chapter: 6, Publisher: Sociedade Brasileira de Carcinologia, Pinheiro \& Boss, p. 103-112.

PEIRÓ DF, WEHRTMAN IS \& MANTELATTO FL. 2014. Reproductive strategy of the ghost shrimp Callichirus major (Crustacea: Axiidea: Callianassidae) from the southwestern Atlantic: sexual maturity of females, fecundity, egg features, and reproductive output. Invertebr Reprod Dev 58(4): 294-305.

PEZZUTO PR. 1998. Population dynaics of Sergio mirim (Rodrigues, 1971) (Decapoda: Thalassinidea: 
Callianassidae) in Cassini Beach, Southern Brazil. Mar Ecol 19(2): 89-109.

PINHEIRO MAA, DUARTE LFA, SOUZA BT, SOARES VS \& NOBRES CR. 2011. Tamanho do quadrado ideal de amostragem e estimativa da densidade de Callichirus major (Say, 1818) (Crustacea, Decapoda, Thalassinidea), em Santos (SP). XIV COLACMAR, Balneário Camboriú, Santa Catarina, Brasil.

RODRIGUES SA. 1983. Aspectos da biologia de Thalassinidea do Atlântico Tropical Americano. Tese de Livre Docência, Instituto de Biociências da Universidade de São Paulo, 174 p. (Unpublished).

RODRIGUES SA, FERREIRA JM, GEBARA HF \& SHIMIZU RM. 1986. Estrutura temporal da população de Callichirus major (Say, 1818) na Baía de Santos, SP (Crustacea, Decapoda, Thalassinidea). XIII Cong Bras de Zoo, Cuiabá, MT, 13: 50.

RODRIGUES SA. 1971. Mud shrimps of the genus Callianassa leach from the Brazilian coast (Crustacea, Decapoda). Arquivos de Zoologia do Estado de São Paulo 20: 191-223.

RODRIGUES AS \& SHIMIZU RM. 1997. Autoecologia de Callichirus major (Say, 1818). Oecol Bras 3: 1555-1570.

RODRIGUES SA, SHIMIZU RM \& COELHO VR. 1994. Monitoramento de uma população de Callichirus major (Say, 1818), da Baía de Santos, SP, sujeita à exploração predatória (Crustácea: Decapoda: Thalassinidea). II CEB, Londrina, PR, 2: 367.

RODRIGUES SA \& SHIMIZU RM. 1990. Considerações sobre a exploração predatória das populações de Callichirus major (Say, 1818) (Crustacea, Decapoda, Thalassinidea) no litoral paulista. An Acad Bras Cienc 62: 201.

SENDIM FS, SOUZA GM S, MCALLAN JP \& CARDOSO RS. 2007. Aspectos reprodutivos de Callichirus major em uma praia do Rio de Janeiro. In: Anais do XII Congresso LatinoAmericano de Ciências do Mar, Florianópolis, p. 15-19.

SOUZA JRB \& BORZONE CA. 2003. A extração de corrupto Callichirus major (Say, 1818) (Crustacea, Thalassinidea) para uso como isca em praias do litoral do Paraná: as populações exploradoras. Rev Bras Zool 20(4): 625-630.

SOUZA JRB, BORZONE CA \& BREY T. 1998. Population dynamics and secondary production of Callichirus major (Crustacea: Thalassinidea) on a southern Brazilian sandy beach. Arch Fish Mar Res 46(2): 151-164.

SPARRE P \& VENEMA SC. 1998 Introduction to tropical fish stock assessment. Part 1 - Manual. FAO Fisheries Technical Paper 306/1. FAO. p. 200-203.

STRASSER KM \& FELDER DL. 1999. Sand as stimulus for settlement in the ghost shrimp Callichirus major (Say,
1818) and C. islagrande (Schmitt, 1935) (Crustacea: Decapoda: Thalassinidea). J Exp Mar Biol Ecol 239: 211-222.

SUCHANEK TH \& COLIN PL. 1986. Rates and effects of bioturbation by invertebrates and fishes at Enewetak and Bikini Atolls. Bull Mar Science 38(1): 25-34.

SUGUIO K. 1973. Introdução à sedimentologia. São Paulo, Edgard Blücher, 317 p.

TAMAKI A \& INGOLE B. 1993. Distributiom of juvenile and adult ghost shrimps, Callianassa japonica Ortmann (Thalassinidea), on na intertidal flat: Intraspecific facilitation as a possible pattern-generating fator. J Crustac Biol 13: 175-183.

WEBB AP \& EYRE BD. 2004. Effect of natural populations of burrowing thalassinidean shrimp on sediment irrigation, benthic metabolism, nutrient fluxes and denitrification. Mar Ecol Prog Ser 268: 205-220.

WEIMER JKT \& HOYT JH. 1964. Burrows of Callianassa major Say, geologic indicators of littoral and shallow neritic environments. J Paleontol 38: 761-767.

WYNBERG RP \& BRANCH GM. 1994. Disturbance associated with bait-collection for sandprawns (Callianassa kraussi) and mudprawns (Upogebia africana): Long term effects on the biota of intertidal sandflats. J Coas Res 52: 523-558.

WYNBERG RP \& BRANCH GM. 1997. Trampling associated with bait collection for sand prawns Callianassa kraussi Stebbing effects on the biota of an intertidal sandflat. Environ Conserv 24: 139-148.

ZAR JH. 1999. Biostatistical analysis, $4^{\text {th }}$ ed., 929 p. Prentice Hall, Upper Saddle River, NJ.

\section{How to cite}

MOSCHETTO FA, DUARTE LFA \& BORGES RP. 2020. Population structure of Callichirus major (Say 1818) (Crustacea: Callianassidae) and conservation considerations at Southeast coast of São Paulo, Brazil. An Acad Bras Cienc 92: e20180795. DOI 10.1590/0001-3765202020180795.

Manuscript received on July 31, 2018; accepted

for publication on April 29, 2019 
Fernanda Augusto Moschetto ${ }^{1,2}$

https://orcid.org/0000-0002-9158-3808

Roberto Pereira Borges ${ }^{3}$

https://orcid.org/0000-0002-5323-9520

\section{Luis Felipe de Almeida Duarte}

https://orcid.org/0000-0002-4658-4684

'University Santa Cecilia/UNISANTA, Coastal

Management Research Group, Rua Osvaldo Cruz,

277, Boqueirão, 11045-407 Santos, SP, Brazil

${ }^{2}$ São Paulo State University (UNESP), Coastal

Management Laboratory, Praça Infante Dom Henrique,

Parque Bitaru, 11330-900 São Vicente, SP, Brazil

${ }^{3}$ Federal University of São Paulo (UNIFESP),

Department of Marine Sciences, Rua Silva

Jardim, 136, 11015-020 Santos, SP, Brazil
Correspondence to Fernanda Augusto Moschetto

E-mail:fernanda_moschetto@hotmail.com

\section{Author contributions}

Moschetto FA developed this study, processed the data, performed the analysis, interpreting the results and worked on the manuscript. Duarte LFA verified the statistical analysis and worked on the manuscript. Borges RP conceived of the presented idea, contributed to sample preparation, interpreting the results and supervised the findings of this work. All authors discussed the results and contributed to the final manuscript and revisions.

(cc) BY 